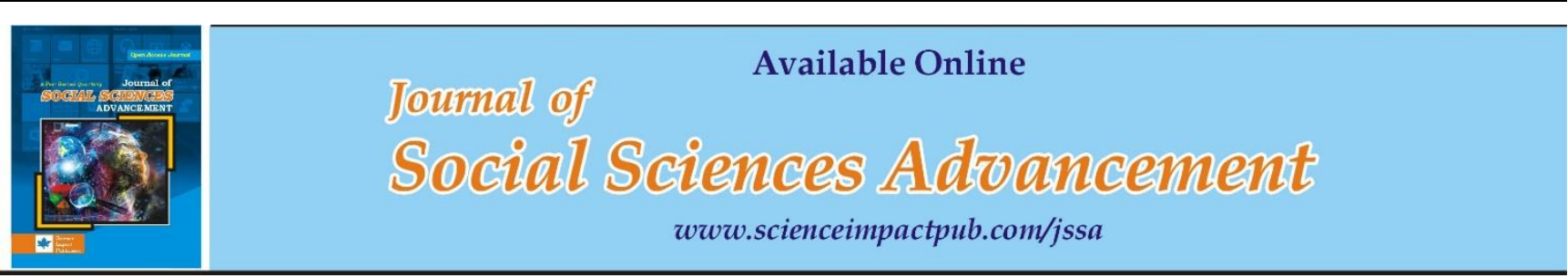

\title{
A COMPARISON OF ENGLISH READING TEXTS IN TEXTBOOKS AND GRADE 9 NATIONAL EXAMS
}

\author{
Pornpimon Tangsakul' ${ }^{1}$ Wachiraporn Kijpoonphol ${ }^{2}$ and Nguyen Duy Linh ${ }^{3}$ \\ ${ }^{1}$ Foreign Language Department, Ban Rung School, Sisaket, Thailand \\ ${ }^{2}$ Faculty of Liberal Arts, Ubon Ratchathani University, Ubon Ratchathani Province, Thailand \\ ${ }^{3}$ Faculty of Liberal Arts and Sciences, Roi Et Rajabhat University, Roi Et, Thailand
}

\begin{abstract}
This study aimed to investigate the English reading texts in Team-Up in English 1-3 and Grade 9 National Exams or English Ordinary National Educational Test (O-NET) examinations (2014-2017) in terms of reading text types and also take a look at tenses and aspects in the reading texts. Reading texts were collected and analyzed quantitatively by frequency count and qualitatively based on the categories of NSW (New South Wales) Government Education (2011). Twelve tenses and aspects were used to analyze tenses and aspects of the reading passages. Result revealed that the most frequently found text type in both the textbooks and the 0-NET examinations was Information Report. Most tenses and aspects found were present simple, and past simple.
\end{abstract}

Keywords: Reading text; English textbooks; O-NET; National exams; Team-Up in English 1-3; Reading text types; Tenses and aspects

Corresponding Author: Wachiraporn Kijpoonphol, Email: wachiraporn.k@ubu.ac.th

(C) The Author(s) 2020.

\section{INTRODUCTION}

Thailand's Basic Education Core Curriculum 2008 (BECC2008) has designed the measurements and evaluations in educational servicesat four levels: grade level, school level, area level, and national level. Evaluation results can in turn be used as a guideline for educational development, which will truly enhance educational quality.

The most important teaching and learning materials which guide teachers and students in almost all classes towards a national test of every kind are textbooks. Thus, basic tools in learning English are textbooks. It is considered as the foundational language inputs that students are required toobtain and apply in practicinglanguage skills inside and outside the classroom (Behlol \& Nasab, 2016). Tandlichova (2003) also considered the textbook as a means of classroom management for the teacher and students in a learning process. He also considered textbook to be a curricular object, which is the source of knowledge for students and teaching materials for teachers. According to National Educational Act 1999 (Ministry of Education, 1999) Chapter 9, Section 64, the state should provide and support the use of textbooks, reference books, academic books, publication, materials, and other technologies for education, financial provision for production, motivation for producers, and development of educational technologies.

However, English textbooks written or selected by the Ministry of Education are well-suited with National Educational Act 2008 (Ministry of Education, 2001). At present, in order to choose the textbook for teaching, the teachers do not concern only the compatibility between the contents in the textbooks and the Basic Education Core Curriculum, but also take a look at how they are relevant to the national exams or henceforth named Ordinary National Education Tests (O-NET) since the O-NET scores can determine the learning quality of the nation (Sukying, 2010). The measurements and evaluations of Thai students are in the form of the testthat is designed to evaluate the quality of students' learning that should be consistent withthe learning standards of BECC 2008 (Ministry of Education, 2008). The results of the test are also utilized as a guideline signifying educational quality of Grade 6, 9 and 12 students, and for individual students, which may lead to the improvement of education system afterward. Besides, the results of the assessment canrevealwhetheror notschools haveaugmented their education tograsp the standard. Furthermore, they also show the proficiency of individual students.

The O-NET, which is a written examination, is a mandatory and high-stack examination. The scores got from 0-NET and school based evaluation which held in relevant academic year, concludes an up-gradation to higher level held during each academic year. As per the National Institute of Education Testing Service-Public organization, the 0-NET is dealt ever year by the National Institute of Education Testing Service among Grade 6 (ISCED 1), Grade 9 (ISCED 2), 
Grade 12 (ISCED 3) students in both private and public schools. For Grade 9 English 0-NET examinations, reading comprehension part consists of 15-20 test items. Each item scores 2 points. The total score of all parts is 100 . The minimum requirement to meet the national standard was 50\% (National Institute of Education Testing Service, 2015).

It seems that choosing textbooks takes a big part in the teaching. This may be because the textbooks are "the most important elements of teaching process for aims and objectives of a course" (Anjaneyulu, 2014, p. 816). However, there are numerous English textbooks available. It is important for teachers to choose the most suitable one to respond to the needs of students. In reality, choosing textbooks mainly focuses on how much budget the schools have. In one of the northeastern provinces of Thailand, the school-network areas consist of many nearby-schools. Schools can select their own English textbooksand they have different versions, but the most popular textbook that they put into usein this area is Team-Up in English. As textbooks are the main teaching tools for schools in this area, the contents the students learn from the books are mainly the learning sources for them. The knowledge the students gain is mostly from the textbooks.

According to Hyon (2002), the students need to know the genres of reading to understand the reading in the language of the test they are doing, besides other learning skills. Moreover, the textbooks can lead the students to a narrow range of reading genres. This may not be diverse and useful for students' future learning. Therefore, there is a need to consider materials in teaching readings, whether or not they are similar to the tests (Saiyasomnut, 2012). Moreover, some researchers found that the types of reading genre can be one of the causes for difficulty in reading. Learning the rhetorical function of different genres takes considerable practice as well as knowledge of a discipline's way of conducting questions and making arguments. However, according to Hyon (2002), understanding the nature of different genres help students to improve and know the techniques to use in a reading passage more easily as it helps them know how the texts are constructed and feel familiar with the text structures. Likewise, the students do best at what they have learned and practiced (Day \& Park, 2005). Therefore, it is also important to note that, without adequate reading skills, learners with comprehension difficulties may be unable to deal with those difficulties that they experience in understanding what they read (Woolley, 2011).

Since the textbooks are considered as teaching and learning materials, they ascertain the components and methods of learning such as methods, content, and learning procedures. To be considered as good textbooks, Ansary and Babaii (2002) noted that they should be a good source for other instructional areas. For instance, the good textbooks should be a good source for subject matters and cover that certain subject, a source for information recheck on doing experiment, proving theories with other learning sources, a source of activities and self-learning guideline, be a systematically kit for learning developing, and a source of motivation for scholars to write other supportive books.

\section{LANGUAGE CONTENT ANALYSIS}

According to Cunningsworth (1995), language contents can be compared with what learners need and expect to learn. Cunningsworth (1995) suggested that the language content as listed below should be analyzed for effective language teaching and learning.

\section{Language form and language use}

According to Cunningsworth (1995), textbooks are a major source of language teaching and learning. In order to understand the contents, the readers must understand the language form and language use. Language form refers to the mechanics of the language, either in term of grammar or vocabulary. With regards to grammar, the readers must understand the sentence structure of a specific grammar rule. With regards to vocabulary, the readers must understand the pronunciation of a word. If in a written text, then the readers must know how to spell a word. Students should be able to breakdown the components of a word to guess at the meaning. Students should be capable to use the vocabulary and grammar before getting used to language use. For instance, the past perfect tense is never used in each sentence, but can be in conjunction with the past tense. One sentence appears in the past perfect to order events, and the subsequent sentence appears in the simple past.

\section{Grammar}

The thing to consider is what grammatical items are included and how far they can correspond to students' needs. Grammar is a main component in a language course. When presenting new grammar, it is possible to teach the form without its meaning as the grammatical form is already underlying the use, therefore when introducing new grammar items, textbooks should emphasize the use of their forms (Cunningsworth, 1995).

\section{Tenses and aspects}

Tense is referenced to the moment of speaking. There are three tenses which are present tense, past tense, and future tense. Aspect expresses how the speaker views the action of the verbs. There are four aspects which are simple, continuous, perfect, and perfect continuous. Table 1 shows the form of 12 tenses and aspects in English grammar (Haccius, 2007). 


\section{Language form and language use}

According to Cunningsworth (1995), textbooks are a major source of language teaching and learning. In order to understand the contents, the readers.

Table 1: Form of 12 Tenses and Aspects in English Grammar

\begin{tabular}{|c|c|c|c|c|}
\hline Tenses / Aspects & Simple & Continuous & Perfect & Perfect Continuous \\
\hline Present & $\mathrm{S}+\mathrm{V} 1$ & S+is/am/are+Ving & S+have/has+V3 & S+have/has+be \\
\hline Past & $\mathrm{S}+\mathrm{V} 2$ & S+was/were+Ving & S+had+V3 & S+had+been+Ving \\
\hline Future & S+will+V1 & S+will+V1 & S+will+have+V3 & S+will+have+been+Ving \\
\hline
\end{tabular}

It is assumed that the most frequently used tenses and aspects were present simple, past simple, modals, and present perfect.

\section{READING COMPREHENSION}

Reading is considered as a powerful activity when the readers look at the text and perceive the meaning to the written symbols in the text (Fitria \& Syarif, 2014). According to Fitria and Syarif, (2014), comprehension is the process of understanding words, sentences, connected texts, which requires the readers to make inferences and reading questions. According to Woolley (2011), reading comprehension is the process of making meaning from texts. The goal is to achieve an overall understanding of what is expressed in the text rather than to obtain meaning from isolated words or sentences. In order to understand or comprehend what they read, the readers need to know what they read and have adequate reading skills in learning language (Fitria \& Syarif, 2014).

However, there are two main factors; which affect the reading comprehension (Tompkins, 2014). The first factor is Reader factors which include background knowledge, vocabulary, fluency, comprehension, comprehension skills, and motivation. The second factor is Text factors which include genres, text structures, and text features. When readers are engaged with the text, they think about many things as they read to comprehend the text such as activating previous knowledge, examining the text to uncover its organization, making prediction, connecting to their own experiences, creating mental images, drawing inferences, noticing symbols and other literary devices, and monitoring their understanding (Tompkins, 2014). Therefore, reading comprehension is one of the important factors contributing to success in any examinations because without an-understanding-of the texts, the test takers could notanswer the questions.

\section{TYPES OF READING TEXTS}

Knowing text genres or text types helps students understand the text they are reading. The students can use their understanding of a familiar text type to help them read a new reading text. Then, getting familiar with different text types can help them to understand the text they are reading. NSW Government Education (2011) classifies the text types which are most used as a form of writing at school. There are 2 types of text that are literary text and factual texts. The factual texts aim to give information and facts, whereas literary texts mainly draw out and entertain an emotional response through using language in order to create rational and intellectual images. The factual text type consists of 8 types. The purposes and features of each type are as follows.

First, Factual Description aims to describe a place or a thing by using facts. It begins with an introductory statement, describes different aspects of the subjects systematically and may end with a concluding statement.

Second, Factual Recount aims to retell the previous events which have already been done or happened in time order. It takes a start with previous information such as where, when and who. Then, it depicts the proceedings in time order and can be ended with a personal remarks.

Third, Information Report aims to classify, describe and give factual information about people, animals, things or phenomena. It begins with general classification or definition, and lists a sequence of related information about the topic, and ends with concluding comment.

Forth, Procedure aims to give instructions on how to make or do something. It begins with a statement of goal, lists of materials needed, and gives an instructions that begins with verb in the present tense.

Fifth, Procedure Recount aims to tell how can be done a work at time with full accuracy. It starts with an account that was done, followed by telling how things was made in order, and it was written in the past tense.

Sixth, Explanation aims to explain how or why something happens. It begins by naming the topic, describes items related to the topic, explains how the items related to each other and to each other and to the topic, and may end with a concluding statement. It is written in present tense and may include visual images to support what is written in words.

Seventh, Exposition gives reasons for a point of view to convince the readers. It begins with a sentence that gives a point of view on a topic, followed with reasons and evidences for arguments. It uses convincing language. 
Eighth, Discussion aims to give diverse points of views to decide. It starts with some existing information about the issue, gives evidences for different points of view, and concludes both sides or recommends one point of view.

\section{PREVIOUS STUDIES ON TEXTBOOK AND TEST ANALYSES}

Jivavorranum (2016) studied reading genres and questions in Thai and English textbooks for 0-NET and GAT (General Aptitude Test) examinations. Textbooks used were ICON 2, Mega Goal 2, Moving up Critical Reading 2, Reading Adventures with Writing 2, and Weaving it Together 2. Those textbooks were used by Grade 11 Thai students. The test papers selected for analyzing were Grade 12 O-NET examinations in academic years of 2008-2010, and GAT exam papers from 2009-2010. The study found that two dominant types of reading texts in five textbooks were Information Report and Recount. The two dominant types of questions found in five textbooks were Literal Comprehension and Personal Response Questions. Moreover, questions in Reorganization, Inference, and Evaluation were less found. The dominant genres found in the five examinations were Information Report and Instruction. Recount and Instruction texts were found more frequently than Argumentative and Narrative texts. However, the most dominant type of questions in five examinations was Reorganization Question. Nevertheless, Literal Comprehension Questions found in the examination was still higher than other types of questions.

Some of the previous studies were conducted with the textbooks and the tests, but only few of them studied the relationship between textbooks and the tests in terms of reading texts. Therefore, this research was designed to find out the differences and similarities between Grade 9 English O-NET examinations years 2014-2017 and Team-Up in English 1-3 textbooks in terms of text types. It was also designed to observe tenses and aspects in the reading texts in both textbooks and the 0-NET examinations to find the relationship between the text type and the tenses presented in the textbooks and the tests. The research question was "What text types can be found in the Grade 9 English 0-NET examinations (2014-2017) and Team-Up in English 1-3? How similar and different?"

\section{RESEARCH METHODOLOGY \\ Participants}

1) Textbooks

Team-Up in English 1-3 textbooks were one of the two main sources of data. Team-Up in English 3 was written by Kavanagh, F., Moore, C.L., Morris, C.F., Canaletti, E., Smith, A. \& Cattunar, J. (2015) while Team-Up in English 1 and 2 were written by Kavanagh, F., Moore, C.L., Morris, C.F., Smith, A. \& Cattunar, J. (2015). They all were published by Aksorn Publishing for students Grade7-9. Each textbook consists of 12 units. Only the reading sections in these 12 units were collected and analyzed in terms of text types, which also included the tenses and aspects found in the reading passages.

\section{2) O-NET examination papers}

The English O-NET examinations (2014-2017) designed by the National Institute of Educational Testing Service were used in this study.

\section{3) Research Procedure}

To analyze the types of reading texts in the O-NET examinations and the textbooks, the framework of NSW Government Education (2011) was used. In order to analyze the tenses and aspect of the reading passages in the tests and the textbooks, 12 English tenses and aspect of Haccuis (2007) were used.

\section{4) Data collection}

The text types in Team-Up in English 1-3 were collected from the reading passages in the reading sections only. The total number of reading passages was 66 passages. While the text types in the 0-NET examinations (2014-2017) were collected from the reading sections as well. The total number of reading passages was 21 passages. As part of the analysis of the text types, the tenses and aspects were also analyzed as they laid a basic foundation for a reading comprehension.

The tenses and aspects found in Team-Up in English 1-3 were collected from each sentence of the reading passages in the reading sections. The total number of sentences was 1,396 sentences. The tenses and aspects in 0 -NET examinations (2014-2017) were also collected from the reading sections. The total number of sentences was 204 sentences.

\section{5) Data analysis}

All data were categorized in the table and calculated in percentage for the analysis and discussion. The differences and similarities of text types, and tenses and aspects found between textbooks and O-NET examinations were reported at the end of each data.

\section{RESULTS}

The study looked at the text types in Grade 9 English 0-NET examinations (2014-2017) and Team-Up in English 1-3 to find how they were similar and different. 
Table 2 showed the text types found in the Grade 9 English 0-NET examinations (2014-2017). The most frequently found text types in the O-NET examinations (2014-2017) was Procedure (38.10\%), Information Report (33.33\%), Factual Recount (14.29\%), Factual Description (9.52\%) and Explanation (4.76\%) respectively. Based on the data, Procedure and Information Report were the only two text types, which could be found in every year from 2014-2017. Explanation could be found only in 2017. However, Procedure Recount, Exposition, and Discussion were never presented in any year of the tests from 2014-2017. Examples of text type analysis were as follows.

Table 2 Text Types in Grade 9 English O-NET Examinations (2014-2017)

\begin{tabular}{|c|c|c|c|c|c|c|c|c|c|}
\hline \multirow[b]{2}{*}{ 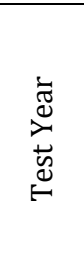 } & \multirow[b]{2}{*}{ 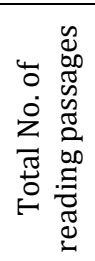 } & \multicolumn{8}{|c|}{ Text Types } \\
\hline & & 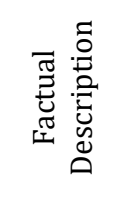 & 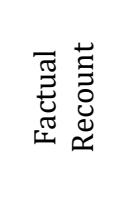 & 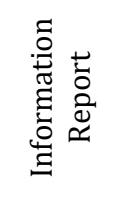 & 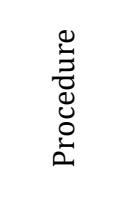 & 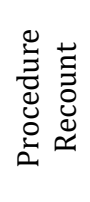 & 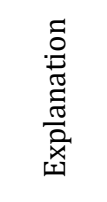 & 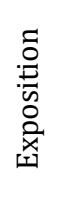 & 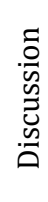 \\
\hline 2014 & 6 & $\begin{array}{c}1 \\
16.67 \%\end{array}$ & $\begin{array}{c}1 \\
16.67 \%\end{array}$ & $\begin{array}{c}1 \\
16.67 \%\end{array}$ & $\begin{array}{c}3 \\
50 \%\end{array}$ & - & - & - & - \\
\hline 2015 & 5 & $\begin{array}{c}1 \\
20 \%\end{array}$ & $\begin{array}{c}1 \\
20 \%\end{array}$ & $\begin{array}{c}1 \\
20 \%\end{array}$ & $\begin{array}{c}2 \\
40 \%\end{array}$ & - & - & - & - \\
\hline 2016 & 5 & - & - & $\begin{array}{c}3 \\
60 \%\end{array}$ & $\begin{array}{c}2 \\
40 \%\end{array}$ & - & - & - & - \\
\hline 2017 & 5 & - & $\begin{array}{c}1 \\
20 \%\end{array}$ & $\begin{array}{c}2 \\
40 \%\end{array}$ & $\begin{array}{c}1 \\
20 \%\end{array}$ & - & $\begin{array}{c}1 \\
20 \%\end{array}$ & - & - \\
\hline Total & 21 & $\begin{array}{c}2 \\
9.52 \% \\
\end{array}$ & $\begin{array}{c}3 \\
14.29 \% \\
\end{array}$ & $\begin{array}{c}7 \\
33.33 \% \\
\end{array}$ & $\begin{array}{c}8 \\
38.10 \% \\
\end{array}$ & - & $\begin{array}{c}1 \\
4.76 \% \\
\end{array}$ & - & - \\
\hline
\end{tabular}

Table 3 showed the text types found in Team-Up in English 1-3 textbooks. The most text types found in this level were Information Report (34.21\%), followed by Factual Description (28.95\%), Factual Recount (21.05\%), and Procedure $(10.53 \%)$ respectively. Explanation and Discussion were the least text types found in this book, which were only $2.63 \%$ each. In sum, the text types that could be found in all 3 textbooks were Information Report (34.84\%) and Factual Description (31.82\%). As overall pictures of the three textbooks, Factual Recount (19.70\%), Procedure (7.57\%), Explanation (4.55\%), and Discussion (1.52\%) were found respectively. However, Procedure Recount and Exposition were not discovered in any textbooks. In Table 2, Team-Up in English 1 provided the least text types as compared to Team-Up in English 2 and 3. However, Team-Up in English 3 provided the most variety of text types among these three.

Table 3 Text Types in Team-Up in English 1-3 Textbooks

\begin{tabular}{|c|c|c|c|c|c|c|c|c|c|}
\hline \multirow[b]{2}{*}{ 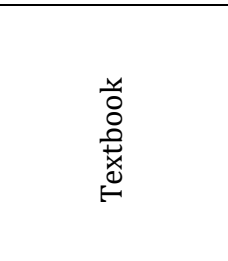 } & \multirow[b]{2}{*}{ 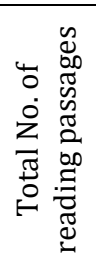 } & \multicolumn{8}{|c|}{ Text Types } \\
\hline & & 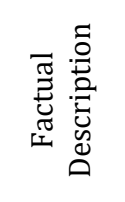 & 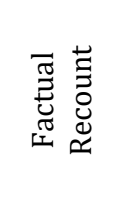 & 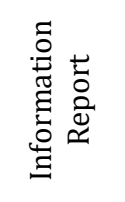 & 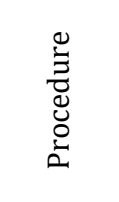 & 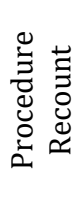 & 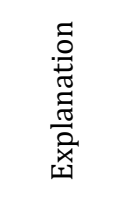 & 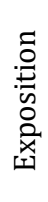 & 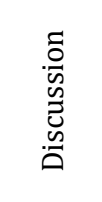 \\
\hline $\begin{array}{c}\text { Team-Up in Eng } \\
1\end{array}$ & 12 & $\begin{array}{c}4 \\
33.33 \%\end{array}$ & - & $\begin{array}{c}6 \\
50 \%\end{array}$ & - & - & $\begin{array}{c}2 \\
16.67 \%\end{array}$ & - & - \\
\hline $\begin{array}{l}\text { Team-Up in Eng } \\
2\end{array}$ & 16 & $\begin{array}{c}6 \\
37.50 \%\end{array}$ & $\begin{array}{c}5 \\
31.25 \%\end{array}$ & $\begin{array}{c}4 \\
25 \%\end{array}$ & $\begin{array}{c}1 \\
6.25 \%\end{array}$ & - & - & - & - \\
\hline $\begin{array}{l}\text { Team-Up in Eng } \\
3\end{array}$ & 38 & $\begin{array}{c}11 \\
28.95 \%\end{array}$ & $\begin{array}{c}8 \\
21.05 \%\end{array}$ & $\begin{array}{c}13 \\
34.21 \%\end{array}$ & $\begin{array}{c}4 \\
10.53 \%\end{array}$ & - & $\begin{array}{c}1 \\
2.63 \%\end{array}$ & - & $\begin{array}{c}1 \\
2.63 \%\end{array}$ \\
\hline Total & 66 & $\begin{array}{c}21 \\
31.82 \% \\
\end{array}$ & $\begin{array}{c}13 \\
19.70 \%\end{array}$ & $\begin{array}{c}23 \\
34.84 \% \\
\end{array}$ & $\begin{array}{c}5 \\
7.57 \% \\
\end{array}$ & - & $\begin{array}{c}3 \\
4.55 \% \\
\end{array}$ & - & $\begin{array}{c}1 \\
1.52 \%\end{array}$ \\
\hline
\end{tabular}

Table 4 showed text types found in the 0-NET examinations and the Team-Up in English 1-3 textbooks. The most text type found in the textbooks was Information Report (34.84\%), while Procedure (38.10\%) was the most text type found in the tests. The least text type found in the textbooks was Discussion $(1.52 \%)$, while the least text type found in the tests was Explanation (4.76\%).

To answer the research question, the study found the similarity between the tests and the textbooks was that Factual Description, Factual Recount, Information Report, Procedure, and Explanation were found in both of them. However, Discussion $(1.52 \%)$ was found only in the textbooks, but was not presented in any tests. Nevertheless, Procedure Recount and Exposition were not found in any tests and textbooks. 
Table 4 Text Types Found in Grade 9 English 0-NET Examinations and Team-Up in English 1-3 Textbooks

\begin{tabular}{|c|c|c|c|c|c|c|c|c|c|}
\hline \multirow[b]{2}{*}{ 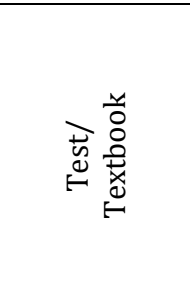 } & \multirow[b]{2}{*}{ 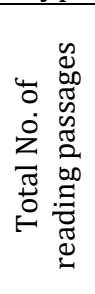 } & \multicolumn{8}{|c|}{ Text Types } \\
\hline & & 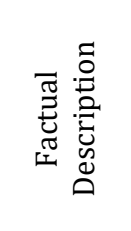 & 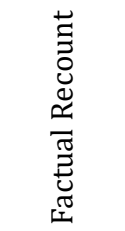 & 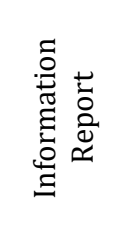 & 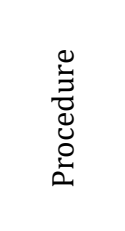 & 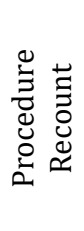 & 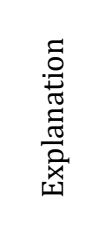 & 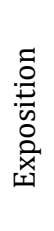 & 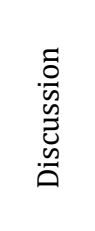 \\
\hline $\begin{array}{l}\text { Team-Up in } \\
\text { Eng 1-3 }\end{array}$ & 66 & $\begin{array}{c}21 \\
31.82 \%\end{array}$ & $\begin{array}{c}13 \\
19.70 \%\end{array}$ & $\begin{array}{c}23 \\
34.84 \%\end{array}$ & $\begin{array}{c}5 \\
7.57 \%\end{array}$ & - & $\begin{array}{c}3 \\
4.55 \%\end{array}$ & - & $\begin{array}{c}1 \\
1.52 \%\end{array}$ \\
\hline $\begin{array}{c}\text { O-NET } 2014- \\
2017\end{array}$ & 21 & $\begin{array}{c}2 \\
9.52 \% \\
\end{array}$ & $\begin{array}{c}3 \\
14.29 \% \\
\end{array}$ & $\begin{array}{c}7 \\
33.33 \% \\
\end{array}$ & $\begin{array}{c}8 \\
38.10 \% \\
\end{array}$ & - & $\begin{array}{c}1 \\
4.76 \% \\
\end{array}$ & - & - \\
\hline
\end{tabular}

To answer the similarities and differences in reading texts between Team-Up in English 1-3 and the 0-NET examinations (2014-2017) in terms of tenses and aspects, the resultsare shown in Table 5 below.

Table 5 Tenses and Aspects in Reading Texts in Grade 9 English 0-NET Examinations

\begin{tabular}{|c|c|c|c|c|c|c|c|c|c|c|c|c|c|}
\hline \multirow[b]{2}{*}{$\stackrel{\bar{\nu}}{\circlearrowright}$} & \multirow[b]{2}{*}{ 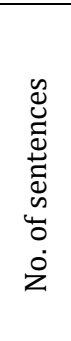 } & \multicolumn{12}{|c|}{ Tenses } \\
\hline & & 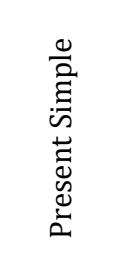 & 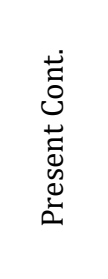 & 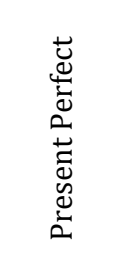 & 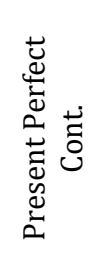 & 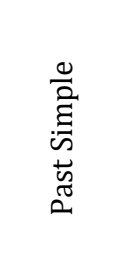 & 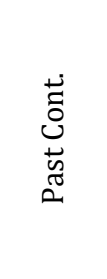 & 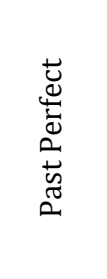 & 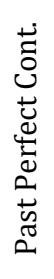 & 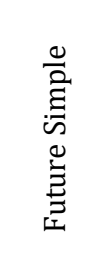 & 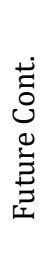 & 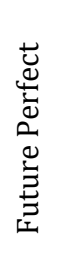 & 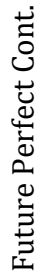 \\
\hline 2014 & 50 & $\begin{array}{c}35 \\
70 \%\end{array}$ & $\begin{array}{c}1 \\
2 \%\end{array}$ & $\begin{array}{c}3 \\
6 \%\end{array}$ & - & $\begin{array}{c}8 \\
16 \%\end{array}$ & - & - & - & $\begin{array}{c}3 \\
6 \%\end{array}$ & - & - & - \\
\hline 2015 & 39 & $\begin{array}{c}16 \\
41.03 \%\end{array}$ & $\begin{array}{c}1 \\
2.56 \%\end{array}$ & $\begin{array}{c}3 \\
7.69 \%\end{array}$ & - & $\begin{array}{c}15 \\
38.46 \%\end{array}$ & $\begin{array}{c}1 \\
2.56 \%\end{array}$ & - & - & $\begin{array}{c}3 \\
7.69 \%\end{array}$ & - & - & - \\
\hline 2016 & 55 & $\begin{array}{c}29 \\
52.73 \%\end{array}$ & $\begin{array}{c}3 \\
5.46 \%\end{array}$ & $\begin{array}{c}6 \\
10.91 \%\end{array}$ & $\begin{array}{c}1 \\
1.82 \%\end{array}$ & $\begin{array}{c}12 \\
21.82 \%\end{array}$ & - & $\begin{array}{c}2 \\
3.64 \%\end{array}$ & - & $\begin{array}{c}2 \\
3.64 \%\end{array}$ & - & - & - \\
\hline 2017 & 60 & $\begin{array}{c}15 \\
25 \%\end{array}$ & $\begin{array}{c}4 \\
6.67 \%\end{array}$ & $\begin{array}{c}4 \\
6.67 \%\end{array}$ & (1) & $\begin{array}{c}32 \\
53.33 \%\end{array}$ & - & $\begin{array}{c}4 \\
6.67 \%\end{array}$ & - & $\begin{array}{c}1 \\
1.67 \%\end{array}$ & - & - & - \\
\hline Total & 204 & $\begin{array}{c}95 \\
46.57 \% \\
\end{array}$ & $\begin{array}{c}9 \\
4.41 \% \\
\end{array}$ & $\begin{array}{c}16 \\
7.84 \% \\
\end{array}$ & $\begin{array}{c}1 \\
0.49 \% \\
\end{array}$ & $\begin{array}{c}67 \\
32.84 \% \\
\end{array}$ & $\begin{array}{c}1 \\
0.49 \% \\
\end{array}$ & $\begin{array}{c}6 \\
2.94 \% \\
\end{array}$ & - & $\begin{array}{c}9 \\
4.41 \% \\
\end{array}$ & - & - & - \\
\hline
\end{tabular}

Table 5 showed tenses and aspects found in reading passages in Grade 9 English O-NET examinations years 20142017. The most frequency of tenses and aspects found in Grade 9 English O-NET examinations (2014-2017) was present simple with $46.57 \%$, while past simple, and present perfect were found at 32.84\% and $7.84 \%$ respectively. Present continuous and future simple appeared at the same percentage at $4.41 \%$, followed by past perfect ( $2.94 \%$ ). The least frequency of tenses and aspects were present perfect continuous and past continuous at $0.49 \%$. The similarity of the tests years 2014-2017 was the high percentage of tenses and aspects found in the tests were present simple and past simple respectively.

Table 6 showed tenses and aspects found in reading passages in Team-Up in English 1-3 textbooks. The most frequency of tenses found in all three textbooks was present simple (64.61\%) and present perfect (3.73\%). However, past simple had higher percentage of frequency of tenses found in textbooks than present perfect at $26 \%$, but it was found only in Team-Up in English 2-3. Present continuous did not appear in Team-Up in English 2, but it presented in Team-Up in English 1 and 3. Moreover, past simple, past continuous, and future simple were not found in Team-Up in English 1, but they appeared in Team-Up in English 2-3.

Table 7 showed the tenses and aspects found in the reading texts in Grade 9 English 0-NET examinations (20142017) and Team-Up in English 1-3 textbooks. The most frequency of tenses found in both the O-NET examinations and the textbooks was the present simple, followed by the past simple. However, in 2017 the most frequently tense and aspect found were past simple. Present simple was found in Team-Up in English 1-3 at 56.38\% while in the 0NET examinations 2014 at 2.19\%, 2015 at 1\%, 2016 at 1.81\%, and 2017 at $0.94 \%$. The past simple was found in Team-Up in English 1-3 at 22.69\%, while in the 0-NET examinations 2014 at 0.5\%, 2015 at 0.94\%, 2016 at $0.75 \%$, and 2017 at $2 \%$. Moreover, the third frequently tense and aspects found in all the textbooks and O-NET examinations (2014-2017) was present perfect at 3.25\%, 0.19\%, 0.19\%, 0.38\%, and 0.25\% respectively. Another tense and aspect found in all textbooks and O-NET examinations (2014-2017) were future simple at 1.31\%, 0.19\%, 0.19\%, 0.13\%, and $0.06 \%$ respectively in the low percentages. 
Table 6 Tenses and Aspects in Reading Passages in Team-Up in English 1-3 Textbooks

\begin{tabular}{|c|c|c|c|c|c|c|c|c|c|c|c|c|c|}
\hline \multirow[b]{2}{*}{ 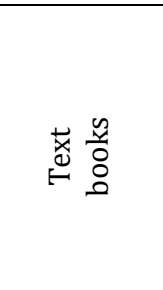 } & \multirow[b]{2}{*}{ 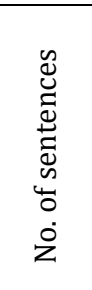 } & \multicolumn{12}{|c|}{ Tenses } \\
\hline & & 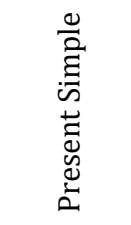 & 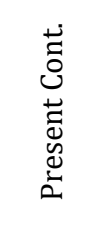 & 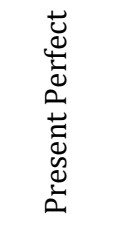 & 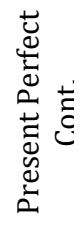 & 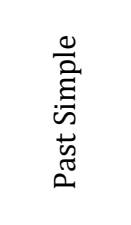 & $\begin{array}{l}\dot{\Xi} \\
\tilde{0} \\
\tilde{u} \\
\tilde{n} \\
\tilde{0}\end{array}$ & 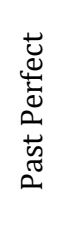 & 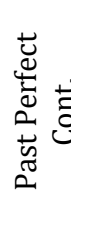 & 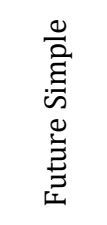 & 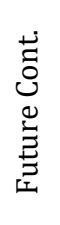 & 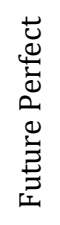 & 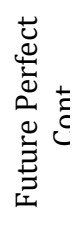 \\
\hline Team-Up 1 & 263 & $\begin{array}{c}235 \\
89.35 \%\end{array}$ & $\begin{array}{c}19 \\
7.22 \%\end{array}$ & $\begin{array}{c}9 \\
3.42 \%\end{array}$ & - & - & - & - & - & - & - & - & - \\
\hline Team-Up 2 & 301 & $\begin{array}{c}165 \\
54.82 \%\end{array}$ & - & $\begin{array}{c}3 \\
1 \%\end{array}$ & - & $\begin{array}{c}126 \\
41.86 \%\end{array}$ & $\begin{array}{c}6 \\
1.99 \%\end{array}$ & - & - & $\begin{array}{c}1 \\
0.33 \%\end{array}$ & - & - & - \\
\hline Team-Up 3 & 832 & $\begin{array}{c}502 \\
60.34 \%\end{array}$ & $\begin{array}{c}22 \\
2.64 \%\end{array}$ & $\begin{array}{c}40 \\
4.81 \%\end{array}$ & - & $\begin{array}{c}237 \\
28.49 \%\end{array}$ & $\begin{array}{c}11 \\
1.32 \%\end{array}$ & - & - & $\begin{array}{c}20 \\
2.40 \%\end{array}$ & - & - & - \\
\hline Total & 1,396 & $\begin{array}{c}902 \\
64.61 \% \\
\end{array}$ & $\begin{array}{c}41 \\
2.94 \%\end{array}$ & $\begin{array}{c}52 \\
3.73 \% \\
\end{array}$ & - & $\begin{array}{l}363 \\
26 \%\end{array}$ & $\begin{array}{c}17 \\
1.22 \%\end{array}$ & - & - & $\begin{array}{c}21 \\
1.50 \%\end{array}$ & - & - & - \\
\hline
\end{tabular}

Table 7 Tenses and Aspects Found in Reading Texts in Grade 9 English 0-NET Examinations and Team-Up in English 1-3 Textbooks

\begin{tabular}{|c|c|c|c|c|c|c|c|c|c|c|c|c|c|}
\hline \multirow[b]{2}{*}{ 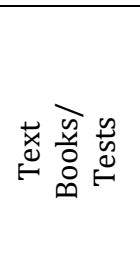 } & \multirow[b]{2}{*}{ 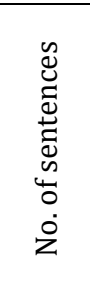 } & \multicolumn{12}{|c|}{ Tenses } \\
\hline & & 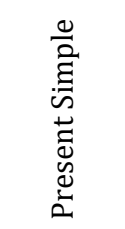 & 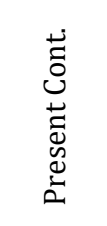 & 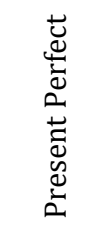 & 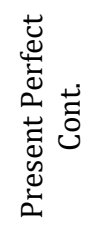 & 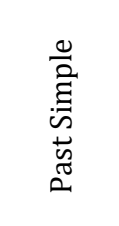 & 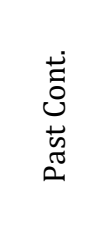 & 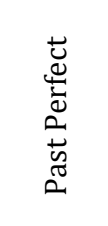 & 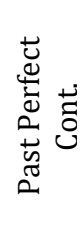 & 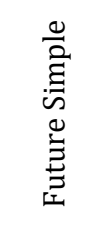 & 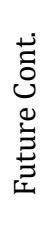 & 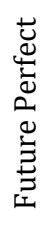 & 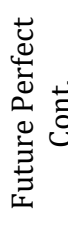 \\
\hline $\begin{array}{c}\text { Team-Up } \\
1-3\end{array}$ & 1,396 & $\begin{array}{c}902 \\
56.38 \%\end{array}$ & $\begin{array}{c}41 \\
2.56 \%\end{array}$ & $\begin{array}{c}52 \\
3.25 \%\end{array}$ & - & $\begin{array}{c}363 \\
22.69 \%\end{array}$ & $\begin{array}{c}17 \\
1.06 \%\end{array}$ & - & - & $\begin{array}{c}21 \\
1.31 \%\end{array}$ & - & - & - \\
\hline 2014 & 50 & $\begin{array}{c}35 \\
2.19 \%\end{array}$ & $\begin{array}{c}1 \\
0.06 \%\end{array}$ & $\begin{array}{c}3 \\
0.19 \%\end{array}$ & - & $\begin{array}{c}8 \\
0.5 \%\end{array}$ & - & - & - & $\begin{array}{c}3 \\
0.19 \%\end{array}$ & - & - & - \\
\hline 2015 & 39 & $\begin{array}{c}16 \\
1 \%\end{array}$ & $\begin{array}{c}1 \\
0.06 \%\end{array}$ & $\begin{array}{c}3 \\
0.19 \%\end{array}$ & - & $\begin{array}{c}15 \\
0.94 \%\end{array}$ & $\begin{array}{c}1 \\
0.06 \%\end{array}$ & - & - & $\begin{array}{c}3 \\
0.19 \%\end{array}$ & - & - & - \\
\hline 2016 & 55 & $\begin{array}{c}29 \\
1.81 \%\end{array}$ & $\begin{array}{c}3 \\
0.19 \%\end{array}$ & $\begin{array}{c}6 \\
0.38 \%\end{array}$ & $\begin{array}{c}1 \\
0.06 \%\end{array}$ & $\begin{array}{c}12 \\
0.75 \%\end{array}$ & - & $\begin{array}{c}2 \\
0.13 \%\end{array}$ & - & $\begin{array}{c}2 \\
0.13 \%\end{array}$ & - & - & - \\
\hline 2017 & 60 & $\begin{array}{c}15 \\
0.94 \%\end{array}$ & $\begin{array}{c}4 \\
0.25 \%\end{array}$ & $\begin{array}{c}4 \\
0.25 \%\end{array}$ & - & $\begin{array}{c}32 \\
2 \%\end{array}$ & - & $\begin{array}{c}4 \\
0.25 \%\end{array}$ & - & $\begin{array}{c}1 \\
0.06 \%\end{array}$ & - & - & - \\
\hline Total & 1,600 & $\begin{array}{c}997 \\
62.31 \% \\
\end{array}$ & $\begin{array}{c}50 \\
3.13 \% \\
\end{array}$ & $\begin{array}{c}68 \\
4.15 \% \\
\end{array}$ & $\begin{array}{c}1 \\
0.06 \%\end{array}$ & $\begin{array}{c}430 \\
26.88 \% \\
\end{array}$ & $\begin{array}{c}18 \\
1.13 \% \\
\end{array}$ & $\begin{array}{c}6 \\
0.38 \% \\
\end{array}$ & - & $\begin{array}{c}30 \\
1.88 \% \\
\end{array}$ & - & - & - \\
\hline
\end{tabular}

To find the similarities and the differences in tenses and aspects in the reading texts from the textbooks and the 0 NET examinations, the results showed that the most frequently tense and aspect found in Team-Up in English 1-3 was present simple, similar to the O-NET examinations (2014-2017). However, the most frequently tense and aspect found in the 0-NET examination 2017 was past simple. The similarity between Team-Up in English 1-3 and the 0-NET examinations (2014-2017) was present continuous, present perfect, and future simple found in all of them, and past continuous was only found in Team-Up in English 1-3 and the 0-NET examination 2015. However, the difference was that present perfect continuous appeared only in 0-NET examination 2016, and past perfect was found in only the 0NET examinations 2016 and 2017.

\section{DISCUSSION}

According to the data, mostly found text types in Team-Up in English 1-3 were Information Report and Discussion, and mostly found text types in Grade 9 English 0-NET examinations (2014-2017) were Procedure and Information Report. Therefore, the similar between these two are Information Report, which mainly aimed to provide real information about animals, people, phenomenon or things in the reading texts. The results showed that most tens es and aspects found in both the textbooks and the 0-NET examinations were present simple and past simple, which related to the most type of reading texts found in both of them (Information Report, Factual Description, and Procedure), since these text types required present simple and past simple to write the texts.

\section{Text types}

This study found that the most text types found in Grade 9 English O-NET examinations (2014-2017) were Procedure and Information Report, while Procedure Recount, Exposition, and Discussion were not present in any year of the tests. The possible reason was that the test writers wanted to focus on Information Report and Procedure based on the Basic Education Core Curriculum 2008, which focuses on Strand 1 (Language for communication), and Strand 2 (Language and culture) for the 0-NET examinations in this level. 
However, the text types found in Team-Up in English 1-3 textbooks showed the different results. The most frequency of text types found in the textbooks were Information Report and Factual Description. Since Information Report was found in both the textbooks and the O-NET examinations, this text type can help prepare the students in term of form of the texts, sentences structure, and familiarity with the words. There are two main factors, which affect the reading comprehension. The first factor is reader factors including background knowledge, vocabulary, fluency, comprehension strategies, comprehension skills, and motivation. The second factor is text factors including genres, text structures, and text features (Tompkins, 2014).

Therefore, getting familiar with the text type can help prepare the students for the tests. For example, Information Report was most found in the textbook, which aimed to illustrate and give realistic information about things, animals, phenomena, or people. It takes a start with a general definition, general classification, or lists a sequence of topic relevant information, and ends with a final comment (NSW Government Education (2011). So, the more the students get familiar with the text type, the more they tend to know what to expect from the reading text in the tests.

However, the number of reading passages in the textbooks related to Procedure was still in a lower number if compared to the tests. This showed that the textbooks provided less Procedure text types, such as timetables, recipes, diagrams, labels, instructions, manuals, which were mainly found as the majority of text types in the 0-NET examinations. The students may face with difficulty in doing the tests on this type of reading passages. Since Exposition and Discussion were less found in both textbooks and tests, the students will lack of experience in exploring the form of their text types, sentence structures, and words used in the text, which may lead the students to face difficulty doing the next coming tests in the future. Similar to Jivavorranum's (2016) study, it was found that two dominant types of reading texts in five textbooks were Information Report and Recount. The dominant genres found in the five examinations were Information Report and Instruction. Recount and Instruction texts were found more frequently than Argumentative and Narrative texts. Even though, Jivavorranum (2016) conducted a study in Grade 12 , the results showed the similarity to this study.

\section{Tenses and aspects}

In the reading passages in the Grade 9 English O-NET examinations years 2014-2017, there were 8 aspects of tenses found. The most frequency of tenses used in the tests was the present simple and past simple, similar to the tenses found in the textbooks. However, in the textbooks - Team-Up in English 1-3, there were only 6 aspects of tenses, while the present perfect continuous and past perfect appeared only in the tests. This showed that Team-Up in English 1-3 did not prepare the students well in present perfect continuous and past perfect for the tests, since these two tenses and aspects were not presented in the textbooks. However, there was the low number of sentences in the present perfect continuous and past perfect used in the reading passages in the tests.

Since Procedure, Information Report, and Factual Description were the major text types found in both of the tests and the textbooks, the present simple was most used in the reading passages to describe the texts based on their nature of feature of text types. Moreover, factual recount was also most found text type in both the 0-NET examinations and the textbooks, past simple tense was frequently appeared in the texts as well according to its nature of feature text type.

\section{CONCLUSION}

The research found that the most of the occurrence of text types initiated in the 0-NET examinations years 20142017 was Procedure, which was in the form of timetables, medicine label, and instructions. Moreover, Procedure and Information Report were the only text types that could be found in all three textbooks. In textbooks, Procedure was in a form of giving steps of doing something, recipe, and instructions; while Information Report was in the form of passages that described and gave factual information about people, animals, things, or phenomena. However, the most frequent text types shown in Team-Up in English 1-3 was Information Report. A lot of reading texts initiated both in the tests and the textbooks aimed to illustrate and give real information about animals, people, phenomenon or things (NSW Government Education, 2011).

In reading passages, present simple and past simple were the most frequency of tense and aspects found in both 0 NET examinations and Team-Up in English 1-3. Since Procedure and Information Report were most found, present simple tense was needed for contribute the sentences because these two text types required present simple tense. However, past simple tense was also found in reading texts in a high percentage since Factual Recount appeared in both the tests and the textbooks. Past simple tense was used to retell events which had already happened in time order in Factual Recount text type.

\section{PEDAGOGICAL IMPLICATION}

Since the study showed that Procedure and Information Report were the most found text types in both the 0-NET examinations and the textbooks, the teachers can prepare the students with reading tasks that presented in the form of Procedure and Information Report. Since the teachers make use of this study, they will know the weakness and strength of these textbooks in order to prepare the extra tasks to support their students' learning on reading comprehension through each type of reading text type. 
Moreover, to comprehend reading text, students need to comprehend the tenses along with aspects to understand the time event of the story. Teachers can take the advantages of teaching present simple, and past simple to the class because they were most appeared in the O-NET. However, from this research result, teachers know that future continuous, past perfect continuous, future perfect continuous, and, future perfect tense should be less focus when teaching for the O-NET because these tenses and aspects were not presented in any test year from 2014-2017.

\section{REFERENCES}

Anjaneyulu, T. (2014). A critical analysis of the English language textbooks in Andhra Pradesh, India. ELT Research Journal, 3(4), 181-200.

Ansary, H. \&Babaii, E. (2002). Analysis of English Textbooks and Supplementary Reading Books. In Share My Passion, Share My Thoughts. Retrieved May 1, 2017 from http://kruoat.blogspot.com/

Behlol, M. G., \& Nasab, D. (2016). Content Analysis Of English Textbook Taught At Grade 9: Focus On Grammatical Structures And Language Skills. Journal of Research in Social Sciences, 4(2), 122.

Cunningsworth, A. (1995). Choosing your Course book. Macmillan Heineman.

Day, R. R., \& Park, J. S. (2005). Developing Reading Comprehension Questions. Reading in a foreign language, 17(1), 60-73.

Fitria, E., \& Syarif, H. (2014). An analysis of reading comprehension questions in textbooks "English texts in use and look ahead" for senior high school grade X. English Language Teaching (ELT), 2(2).

Haccius, M. (2007). The use of frameworks in teaching tense. Master's Thesis of Brattleboro, Vermont. Retrieved on February 28, 2021 from https://digitalcollections.sit.edu/cgi/viewcontent.cgi?article=1007\&context=ipp_collection

Hyon, S. (2002). Genre and ESL reading: A classroom study. Genre in the classroom: Multiple perspectives, 121-141.

Jivavorranum, T. (2016). A STUDY OF READING GENRES AND QUESTIONS IN THAI AND ENGLISH TEXTBOOKS FOR O-NET EXAMINATIONS. The New English Teacher, 10(2).

Kavanagh, F., Moore, C.L., Morris, C.F., Canaletti, E., Smith, A. \&Cattunar, J. (2015). Team-Up in English 3. Aksorn Publishing.

Kavanagh, F., Moore, C.L., Morris, C.F., Smith, A.\&Cattunar, J. (2015). Team-Up in English 1. AksornPublishing.

Kavanagh, F., Moore, C.L., Morris, C.F., Smith, A.\&Cattunar, J. (2015). Team-Up in English 2. AksornPublishing.

Ministry of Education (1999). National Education Act B.E.2542 (A.D.1999). Bangkok, Thailand: Office of the National Education. Commission. Retrieved May 1, 2017, from http://www.edthai.com/act/index.htm\#Chapter9

Ministry of Education (2001).The Basic Cores Curriculum B.E. 2544 (A.D.2001). Bangkok, Thailand: Office of the National Education.

Ministry of Education (2008). The Basic Core Curriculum B.E. 2551 (A.D.2008). KurusapaLadprao Publishing.

National Institute of Education Testing Service (2015). O-NET (Ordinary National Educational Test).National Institute of Education Testing Service (Public Organization). Retrieved on February 23, 2018 from https://www.niets.or.th/th/catalog/view/241

NSW Government Education (2011).Different types of writing - text types. A NSW Government website - Education. Retrieved May 1, 2018, from https://www.education.nsw.gov.au/parents-andcarers/learning/english/english-a-to-z-support-pages/text-types-different-types-of-writing

Saiyasomnut, S (2012). Thai education failures - Part I: Ridiculous O-NET Questions. http://asiancorrespondent.com/76664/thai-education-part-I-ridiculous-o-net-questions/ (Last accessed 14 October 2015).

Sukying, A. (2010). An analysis of headwords in ELT coursebooks and Ordinary National Educational Tests in Thailand. LSCAC 2010 Proceedings, 188.

Tandlichová, E. (2003). EFL coursebook in learner-centred learning and teaching. Theory and Practice in English Studies, 1, 145-151.

Tompkins, G., Campbell, R., Green, D., \& Smith, C. (2014). Literacy for the 21st century. Pearson Australia. Woolley, G. (2011). Reading comprehension. In Reading Comprehension (pp. 15-34). Springer, Dordrecht.

Publisher's note: Science Impact Publishers remain neutral with regard to jurisdictional claims in published maps and institutional affiliations.

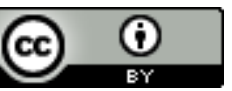

Open Access This article is licensed under a Creative Commons Attribution 4.0 International License, which permits use, sharing, adaptation, distribution and reproduction in any medium or format, as long as you give appropriate credit to the original author(s) and the source, provide a link to the Creative Commons license and indicate if changes were made. The images or other third-party material in this article are included in the article's Creative Commons license, unless indicated otherwise in a credit line to the material. If material is not included in the article's Creative Commons license and your intended use is not permitted by statutory regulation or exceeds the permitted use, you will need to obtain permission directly from the copyright holder. To view a copy of this license, visit https://creativecommons.org/licenses/by/4.0/.

(C) The Author(s) 2020 